\title{
Participation of rural women in farm decision making in Marathwada region
}

\author{
R.P. KADAM ${ }^{1 *}$, S.M. UMATE ${ }^{2}$, G.S. PAWAR ${ }^{2}$ AND A.K. THORAT ${ }^{3}$ \\ ${ }^{2}$ Seed Technology Research Unit (BSP Unit and VNMKV) PARBHANI (M.S.) INDIA \\ ${ }^{3}$ Department of Extension Education, College of Agriculture, Vasantrao Naik Marathwada Krishi \\ Vidyapeeth, PARBHANI (M.S.) INDIA
}

\begin{abstract}
The present study was carried out in Parbhani district. The three tahsils namely, Parbhani, Purna and Gangakhed were selected by lottery method from Parbhani district. From selected each tahsil 40 rural women were selected for the present study. Thus from three tahsils 120 respondents were selected purposively from twelve villages of Parbhani district of Maharashtra State. They were interviewed personally to collect the data with the help of structured interview schedule. The collected data were processed and statistically analyzed. It observed from result that majority $(58.33 \%)$ of the respondents were found in medium decision making followed by 21.67 per cent in low decision making category, whereas only (20.00\%) in high decision making category. There was positive and significant relationship between size of family, type of family, land holding and annual income, while social participation, economic motivation, risk orientation and sources of information was positive and highly significant with their level of participation in farm decision making. Further age was negatively significant relationship between age and decision making and their level of participation in farm decision making.
\end{abstract}

KEY WORDS : Rural women, Participation, Farm decision making

View Point Article : Kadam, R.P., Umate, S.M., Pawar, G.S. and Thorat, A.K. (2014). Participation of rural women in farm decision making in Marathwada region. Internat. J. Home. Sci. Extn. \& Comm. Mgmt., 1 (2): 68-75.

Article History : Received : 01.05.2014; Revised : 10.05.2014; Accepted : 26.05.2014 